Journal of Humanities, Social and Management Sciences (JHSMS)

eISSN: 2788-4791 (online)

https://doi.org/10.47264/idea.jhsms/2.1.9

Vol. 2, No. 1 (January-June 2021), 95-107

https://www.ideapublishers.org/index.php/jhsms

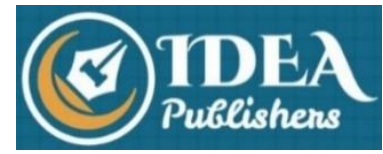

Research Article

\title{
The Utopian concept of free state in Gerald Vizenor's The Heirs of Columbus: An anarchist study
}

\author{
Fayaz Khan*1 ${ }^{1}$ Amir Turkey ${ }^{1} \mid$ Sehrish Ashraf ${ }^{2}$
}

1. Department of English Language and Literature, Hazara University, Mansehra, Pakistan.

2. Department of English, The University of Lahore, Sargodha Campus, Sargodha, Pakistan.

*Corresponding Author Email: fayazpur87@gmail.com

\begin{abstract}
The present research aims to explore the struggle of the marginalized community for a free nation, where individuals try to regain their culture. Gerald Vizenor's The Heirs of Columbus has depicted their longing for survival and cultural liberty. Vizenor has tried to regain the voices of the Native people through trickster stories because these stories have a healing power. The analysis shows that Red-Indians in the late fifteen century were never uncivilized as portrayed by the Western historians and the protagonist resisted for the survival of their unique civilizations. The present research has highlighted that how anarchist spirit stimulated a nation to reclaim their lost culture and identity. Their resistance through anarchist principles leads them towards getting a free state, where every individual try to preserve their culture through trickster stories and moccasin games. The tribal people wanted to represent this state as an anchist Communist state, where there will be no property and land theft. The people will be free from the burden of taxes and prisons. The study concludes with the suggestion to resist power with anarchist spirit of survivance. Future researches are suggested to focus on the theme of marginalization and its strategies in the present novel.
\end{abstract}

Keywords: Red-Indians, marginalized community, survival, anarchist spirit, moccasin games, free state, survivance, communist state.

How to Cite:

Khan, F., Turkey, A., \& Ashraf, S. (2021). The Utopian concept of free state in Gerald Vizenor's The Heirs of Columbus: An anarchist study. Journal of Humanities, Social and Management Sciences (JHSMS), 2(1), 95-107. https://doi.org/10.47264/idea.jhsms/2.1.9

Publisher's Note:

IDEA PUBLISHERS (IDEA Journals Group) stands neutral with regard to jurisdictional claims in the published maps and institutional affiliations.

\section{Copyright:}

(C) 2021 The Author(s), published by IDEA PUBLISHERS (IDEA Journals Group)

This is an Open Access article published under the Creative Commons Attribution-NonCommercial 4.0 International License (http://creativecommons.org/licenses/by-nc/4.0/) 


\section{Introduction}

The Heirs of Columbus (1991) is a blend of fiction and historical facts. The novel deals with the protagonist Stone Columbus who claims to be the descendent of Christopher Columbus, the great explorer. Stone Columbus is a 'cross blood trickster healer' while his wife is named after Christopher Columbus's wife Felipa as Felipa Flowers who in turn is a tribal poacher. The job of the Stone Columbus's wife is to bring back the remains of their cross blood forefather Christopher Columbus and Pocahontas, a tribal princess. It is interesting to note that Felipa Flowers dies on the same date as Pocahontas and this is an intentional subversion of European historical facts and repugnant colonialism. Stone Columbus works on Carp Radio as a host and informs his tribal people about their Mayan ancestor Christopher Columbus. Stone Columbus as the mouth piece of Vizenor not only destroys the European historical and cultural stereotypes about the tribal people, but also reinvents tribal stereotypes to create a true tribal discourse of Native Americans.

When Admiral Lucky White who is the owner of Carp Radio station asked about the birth place of Christopher Columbus, who was Italian as history has recorded, Stone Columbus; the protagonist claims "Columbus was Mayan" (Vizenor, 1991, p. 9). The owner of the Carp Radio is shocked at this answer but Stone Columbus convinces her by saying: "The Mayan brought civilization to the savages of the Old World and the rest is natural, said Stone. Columbus escaped from the culture of death and carried our tribal genes back to the New World" (Vizenor, 1991, p. 9). When Admiral Lucky White again asks Stone that what Christopher was really in search of, Stone Columbus replied that he is looking for gold and tribal women but instead he found his home and Samana. The golden healer Samana, "she touched his soul and set the wounded adventurer free on October 28, 1492, at Bahia de Bariay and in Oriente Province, Cuba" (Vizenor, 1991, p. 10). Therefore, the reference on behalf of Stone to Samana and her meeting with Christopher Columbus implies that it is through Samana that Stone Columbus himself and all the rest of the tribal people have been descended.

The mixing of history and fictive tribal account on behalf of the author clearly depicts an 'act of survivance' to subvert the European cultural stereotyping of tribal people, because the tribal people were not without history. When the Old World (Europeans) was still in dark ages, the New World (Native Americans) had established the Mayan, Aztec and Inca civilizations. The Utopian concept of the "free State" is vivified by Rooum (2016) with a theoretical manifesto of Anarchism. Freedom of individual is what anarchy strives for, unless that freedom of choice will not threaten the free choice of another individual. The book also throws light on the choice of freedom. Anarchy is not a perfect freedom; it is only absence of government, or coercive establishments. Therefore, the anarchists are not presenting a society that will be free from coercive forces but anarchy will always keep a balance and check on all of those coercions (Rooum, 2016).

There is a deeper concept within the fictional delineation of historical record presented by Vizenor. The utopian concept of the "free state" is presented as the ultimate goal of anarchism. Vizenor is therefore inculcating in the minds of his readers that peace and contentment is the ultimate outcome of immense struggle. Point Assinika is that hidden concept of the "free state" which Vizenor tried to convince his readers about. If a colonial master is not challenged and the colonized subjects never attempt to decentralize its power, it is impossible to feel the real essence of the "free state". 


\section{Literature review}

Anarchism is a socio-political economic cluster of theories that is against all kinds of exploitative governments and other such hierarchies that tries to uphold power and then misuses that power (Rooum, 2016). Anarchism is opposed to states, armies, slavery, the wages system, the landlord system, prisons, monopoly capitalism, oligopoly capitalism, state capitalism, bureaucracy, meritocracy, theocracy, revolutionary governments, patriarchy, matriarchy, monarchy, oligarchy, protection rackets, intimidation by gangsters, and every kind of coercive institution.

Many people believed that anarchism was not possible because it was a utopian ideology where the state would cease to exist and that people would not be taking up arms against one another. Anarchism never had promised that but, certainly this did not mean that there should be some state, government or centralized organized authority that could be only good at maintaining property and monopoly of one kind or another. Usually properties and lands had been stolen from the weaker ones. Thus, stealing the culture, identity, language, property, and land have been the invention of the colonizers and that was how the colonizers established their cultural hegemony (Proudhon, 1876).

Goldman (1910) said, "Human laws are invalid, because they are contrary to the laws of nature" (Goldman, 1910, p. 26). So, what then the Anarchists suggest as a remedy for a peaceful society is solidarity and harmony for the collective interests of their fellow beings where individual interests will not be compromised unless and until it encroaches upon the rights of other people. Furthermore, there could be free opportunity where work for living would not be taken as a mean of only earning. Though earning cannot be denied. However, everyone will be free to choose a profession based on his/her interest, which could make it earning with delight. The same free will is applied to every other aspect of human lives (Goldman, 1910).

The French Pierre Joseph Proudhon (1809-1865) and the Russian Kropotkin (1842-1921) were very much pestered by those political scientists or theorists who confirmed the sovereignty of the state and the government which is ruling body of a minority group to be justifiable but to anarchists the 'social contract theory' is an anathema and they say that the social contract theory is unjustifiable, which monopolizes every aspect of people's lives e.g. political, economic, socio-cultural, religious and so Proudhon and Kropotkin were against the social contract theory. The state also serves the interests of the privileged few.

Proudhon was in favour of direct democracy and federation, he wanted that workers should be given justice and the only way to put an end to iniquities in society was to abolish property of the bourgeois, these were the ideas of Proudhon, which landed him among mutualisms' proponent. He wanted that history and collective reason would merge under mutualism but this end could be achieved only by standing against the army, police, priests, politicians who had corrupted the religious, political beliefs in their own favour. He also rejected the notion of transcendence and supported his notion of immanence. Proudhon was the first brave man who acknowledged himself to be anarchist. Thus, he is considered the father of the modern philosophy of anarchism (Prichard, 2013).

The liberty and sovereignty of individuals must be respected and the industries must be democratized so that all people will have the same access to capital reciprocity. The 
government again must be established under industrial democratization and the clergy must not give the primary education and there must be insistence upon practical and professional education rather than making someone a priest scientist. This was Proudhon's politic-economic Mutualist contract that once the social organizations and natural groups of individuals with the same interests will cooperate from bottom to top, they will make loose federations and would be federated. He also adds that instead of elected individual and alienating once own autonomy to a tyrant, rather there must be delegates to represent the interest of cities, industries, workshops and people on all forums through Mutualist contract of association under specific needs of people, only then can they become consecrated morally, politically and economically (Prichard, 2013).

Vizenor's (1991) The Heirs of Columbus is a novel about nine Native American tribal people who gave various predictions through radio broadcast, that Christopher Columbus discovered the New World; America in 1492, is not true, as said by political historians. They rather claimed that Christopher Columbus did not discover the New World but actually, he returned to it. The protagonist whose name is also Columbus claims through radio broadcast that their ancestor Christopher Columbus was of Mayan descent. Another blow on the history is that the political historians believed that Christopher Columbus was impotent and unable to procreate children but in this novel Columbus has argued that when Christopher Columbus first stepped on the American continent, the native people greeted him. Among those who greeted Christopher Columbus, there was also a woman named Samana (a hand-talker, the first woman to greet Christopher Columbus) and the following night they made love to each other. Thus, the current Indian race (the title of the novel's heirs) had been born (Vizenor, 1991).

As the story proceeds we are told that Stone Columbus has been arrested for tribal sovereignty; meaning that his ancestors once made a treaty with the White Colonizers that they could carry on with their tribal sovereignty (Native American culture and their possessions and properties). Nevertheless, the government violated this treaty and Stone Columbus who was the owner of three ships, its moment in water was restricted. The three ships were named after those ships, which were accompanying Christopher Columbus once to the new world in 1492.

Soon we find that nature as well has made interference and capsized two other ships. The next move for Stone Columbus then was to make a nation for his people where they will not be needing any medical care, but their care would consists of natural herbs and shrubs. One more important thing is that there would not be any tax levied which was the curse of Capitalism on the nation. In New Nation which the protagonist Columbus was to make consisted of primitive individual contract. Stone Columbus succeeds in making the New Nation but the state and government sent its military to restrict the nation of the Red-Indians. During resistance, their beloved ones are killed but still Stone Columbus had to resist because resistance lead to survival. Stone Columbus believed that survivance was not a futile struggle but a changing phenomenon which had to show the Red-Indians a way out against the oppression of the state. While Stone Columbus tried to evoke the memories of their ancestors in his people psychologically and through awareness, Felipa Flower's on the other hand was practically involved in such adventures to save her (Red-Indians) heritage. Thus, Felipa Flower too became an anarchist and a poacher to retrieve illegally what legally belongs to them and in the process she is murdered by Doric Miched (the custodian of the remains in a Museum) becomes a martyr and lie with many others who have fought before her and will fight and resist after, to seek the true living. Felipa is buried in 'House of Life', a graveyard which belongs to the tribal. 
She is buried there with the remains of Pocahontas and Christopher Columbus, she didn't waste her life she valued it... and she resisted along with others till her death. Now the heirs are taking practical steps to establish Point Assinika and though the state will even interfere, but the tribal people resisted power structure, keeping in mind her memory. Thus, the struggle goes on (Vizenor, 1991).

In The Heirs of Columbus, Vizenor (1991) had tried to re-imagine history of Native Americans by saying that if Christopher Columbus was the ancestor of the Red-Indians and not the White Colonizers, then, things would have been different. The Heirs of Columbus is a novel which focuses on red-Indians as decedents of Christopher Columbus. Columbus did not discover the American Continent in 1492 but he actually returned to it. America was his ancestral homeland. Christopher Columbus was unaware of his ancestral roots (Vizenor, 1991).

This is an intentional distortion of facts by Vizenor (1991) as he wanted to dig the underlying problems by reimagining Red-Indians' history and its relation to the Christian EmpireBuilders, who used their political history to attack the mentality of the dispossessed $\backslash$ RedIndians to control them psychologically. An argument for the aforementioned statement is presented that there are many views about any subject of history. Different views on the same subject are usual from various political historians; each one is justifying his own narrative of the events. These historians might have been right in their narrative of the events but still they are unaware that taking a particular side meant that still justifying the point of view of the colonizers. The historians are contributing to the power of power-holders willingly or unwillingly, either intentionally or unintentionally (Said, 1978).

Indigenous people are always romanticized and classified as the binary "other" in the historical process of colonialism and imperialism. Colonialism in the strictest sense seems to have ended but the imperial process; which promotes the mind set of Euro-Americans, is still going on. Vizenor (2008) says that Indians cannot be called 'post-colonial' or 'neo-colonial' because the historical process of colonialism is still going on. Therefore, Vizenor (2008) says that Indian shall be called 'Para-colonial'. Para-colonial means colonialism beyond colonialism. This is the ongoing process of imperialism (Vizenor, 2008).

Euro-Americans want to wipe the past of the Indians. The Indians are believed to have no future. The Colonizers also want to exterminate the Indians memory so that they would be unable to reclaim their lost-land rights. Colonizers want to wipe the very remembrance of the Indian people. Vizenor (2008) says, "The Indian" (whatever that may be) must disappear so that America can live" (Vizenor, 2008, p. 402) for the same reason. American new settlers adopted the strategies of assimilation of the Indian people through boarding schools. Moreover, they were either removed from their lands or killed in cold blood.

Indians who were oppressed from the beginning took to the tactics of 'survivance'. In order to counter colonial discourses, the Indians used the tactics of 'survivance' such as rhetorical sovereignty and rhetorics of survivance. According to Vizenor (2008), "Imperialism is a strategy; Survivance, a tactic" (Vizenor, 2008, p. 405). These acts of survivance were important because the strategy of the new settlers was to "Kill the Indian and save the man" (Vizenor, 2008, p. 416).

The America before Columbus was not barbaric. The Native Americans have developed Mayan 
civilization in 700 A.D, which is relevant to the current research because Vizenor (1991) has challenged via this civilization the pristine myth of European historians as they claimed that Columbus discovered the New World. Apart from Mayan civilization in Central America, the Native Americans also had developed the Aztec civilization in 14 century. In 1400 A.D, the Inca's civilization had also begun to expand from Peru to other parts of America. The factual argument is against many European historians that Columbus did not discover the New World; many people were living in America before the Europeans. They (colonizers) put their steps on the American land much later. The anthropological and archaeological historians believed that American continent was once connected via a land bridge with Asia, and it was from there that the Asian hunters while chasing bison and bulls had crossed that bridge. The land bridge connected the region of Alaska with Siberia as it is known in today's world. So, to quote Lord and Burke (1991), "the Western Hemisphere in 1492 had as many people as Europe," Devenan also states that it seems like there were more people in America before 1492 than it was in 1750. The reason was as the Europeans entered the American Continent they introduced incurable diseases, which they had brought with them from Europe. These diseases killed thousands of Native American population amidst warfare (Lord \& Burke, 1991).

The Europeans used to call the Native Americans Ios Indios. Although, the Native inhabitants of America used to call one another as "people" or "real people". The Native American were civilized people. Once Columbus stepped on the land, they presented him with gifts such as cloths and birds etc. Their hospitality was taken as a sign of weakness. They were further considered lazy when they showed their lack of interest for the material wealth. In fact, the Native Americans were more civilized than the Spanish Conquistadors, the French and the English Colonizers (Lord \& Burke, 1991).

In order to survive, the Indian tribes must resist the White Man's Burden encroachment upon the remnants of their culture and education (Kipling, 1899). Vizenor stresses upon the Indian 'tribal stories' and their Indian quaint 'nicknames' to preserve their culture in their stories and each name must tell a story to their progeny. Another problem which annoys Vizenor is that of representation. He says that Indian tribes have always been misrepresented by the dominant colonial culture and even those aspects of tribal culture which were benign had been terminated for the worst aspect of white's culture. Thus, says David Freedberg in The Power of Images, "Representation is miraculous because it deceives us into thinking it is realistic" (Vizenor, 1992, p. 225).

\section{Theoretical framework}

Research is a never-ending task when it comes to the time-frame. But it is the theoretical framework which serves as a guide for the researcher. In light of theoretical framework the researcher focused on specific themes of survivance. Theoretical framework in this research provided the researcher with many issues in which the current research was submerged. There were plethora of issues itself in the framework of anarchism, but only the analytical concept as mentioned before was selected from anarchism theory. Thus, Kumar (2019) said that your theoretical framework shows you a path and directs you towards that path through concepts. In this research the concept of Proudhon and Vizenor were analysed. Thus, in order to be guided and not digressed from the main topic, the researcher selected the theory of Anarchism as a framework. Kinna (2005) defined anarchism as a philosophy that wanted the liberation of peoples from political and economic exploitation. 
Anarchism is a vast theory, ideology and philosophy it includes as many divergent authors; whose main ideal is the same, but their perspective differed only on reaching the idea of Anarchism. Some wanted to reach their goal through peaceful means while others said that they must fight for their rights. Overall, all anarchists are the same and want to get rid of cruelties and exploitations whether economic, political, social or cultural. The analytical concepts that were applied on the selected novel The Heirs of Columbus was analysed under Vizenor's concept of survivance and Proudhon's concept as Property is Theft. The two concepts were thoroughly analyzed in the data analysis chapter.

\section{Research methodology}

The present research is qualitative in nature, followed by textual, thematic and critical analysis of Gerald Vizenor's novel The Heirs of Columbus. Qualitative research in most part intends to achieve in-depth understanding (Patton, 2002). The original text of the novel will be used as primary source to support the main aim of the research. The utopian concept of the Free State in The Heirs of Columbus will be analyzed under the analytical concept of Anarchism. The textual analysis of the text will help in analyzing the strong bond between man and culture. It will also be observed that anarchism can lead towards the foundation of a free state, which is not possible without challenging the colonial authority. The data was mainly collected in library and from internet sources. In this qualitative research the hypotheses corresponds to questions (Creswell, 2007). Thus, once the hypotheses have been formulated it led to the overall strategy of research methods and procedures. The overall plan of research methods and procedures is called the research process while once the blueprint of the research plan is formulated, then, the implementation of the plan becomes the design of the research. The research process asks what techniques are used during the process of conducting the research.

Some of the elements during this research process are as followed. Firstly, a gap was found in the Post-Colonial Studies by viewing related literature. Once the gap was found, a theory was selected to explore the relationship between the colonizers and the colonized. Secondly, statement of the problem was made on the basis of the anarchist concept of property is theft with special reference to survivance of the colonized people, which had been more than mere survival. The two concepts were studied under the theoretical framework of anarchism; focusing on the Red-Indians. Thirdly, a working hypothesis (research question/s) was developed, that was survival through resistance with specific reference to the colonized people. Once the hypothesis was developed, questions were produced on the basis of the hypothesis. A working hypothesis is a proposed explanation for a phenomenon that is provisionally accepted, the goal of such hypothesis is to explore and discover new knowledge. They are provisionally accepted since the information provided is new and needs further explorations (Mishra \& Alok, 2017). The selected hypothesis helped in exploring the concept of survivance under anarchism theory, it also helped in relating the problem statement to the Third World colonies and the impact of colonization on the colonized Red-Indians and Moors. Research questions were formulated on the basis of hypothesis and ultimately, answered in the data analysis chapter. But first the data was collected and then it was analysed in the light of the theoretical framework of anarchism.

\section{Data analysis}

Anarchism opposes government in all its forms. Power in itself becomes harmful when those 
who once made tall claims that they would utilize their power to maintain order and peace. They had rather abused it. What if the one who was assigned the duty of power to keep order eventually started misusing it? This is where Anarchists interject themselves in the form of saviours, a hammer to cut those power shackles which aims not at the liberation of people but rather making them slaves. Thence, Anarchism becomes the housefly to consume the filth of the powerful filthy rich who tries to seize the property, government and establishment, industries, factories and politics to work for their own benefits rather than for their fellow human beings at large. Anarchism is against all authoritarian institutions. Anarchism stands for all that plethora of different political economic theories which are anti-authoritarian, antigovernment, anti-state, anti-religion, anti-capitalism, anti-nationalism, anti-property, antiindustries, anti-feudalism, anti-patriarchy, anti-matriarchy, anti-power, anti-exploitation, anticruelty and unjust societies and anything including language power which suppresses men and women alike (Rooum, 2016).

Many people believed that anarchism was not possible because it was a utopian ideology where the state would cease to exist and people would not be taking up arms against one another was impossible. Anarchism never had promised that but, certainly this did not mean that there should be some state, government or centralized organized authority that could be only good at maintaining property and monopoly of one kind or another. Usually, properties and lands had been stolen from the weaker ones. So, stealing the culture, identity, language, property, and land have been the invention of the colonizers. That was how the colonizers established their cultural hegemony (Proudhon, 1876; Awan \& Fatima, 2019).

Berkman (1977) argued that people might be worried about "Security and public order". Whatever order and security that we have today is not because of the government but because of the joint efforts of the people. They use their sixth sense. Man is a social being helshe cannot live in solitude. Man always looks for people with same interest. We have artists, scientists and writers etc. These people have been tied to one another by the same interests. He means that joint effort or co-working does not need any interference of government. It could be mentioned that state, government, police and army cannot stop a citizen to step in front of a car. They cannot stop a man from jumping off from a skyscraper. Human beings are not guided by some external forces such as state but by their free will. Free will could result in mutual understanding, and, mutual understanding could result in mutual arrangements. Thus, security and order would be maintained by the very people. Anti-anarchists claim that order can only be maintained through government. But Anarchist argued that government itself creates disorder in order to monopolize and establish its own hegemony (Berkman, 1977).

Vizenor (1991) in The Heirs of Columbus has challenged the Euro-centric narratives of the Colonizers by moving away from the traditional form of storytelling or narrative-techniques of narratology to stand against the "legacies of colonial violence" and to challenge the Western culture, and history (Sabzalian, 2019). In order to show resistance for a better survival and to talk about biased Native American histories (the original inhabitants of America) from his own stand point as Red-Indian. Gerald Vizenor challenges the political history and creates one of his own. Although Gerald Vizenor never liked the use of the term "Indian" or "Indianness" as he argued that the Native Americans were not only physically, socially, morally, politically, culturally exploited but there have always been an effort from the scholars to dominate them through language and symbols. So, indigenous communities did need anti-colonial literacy and that has been provided by stories of survivance. Survivance stories are helping Indigenous 
communities to reimagine their past, feel, think and act against the colonizers (Stanton, 2020). Such descant makes him a great semiotician to examine the various symbols of languagesystem to cope with such exploitative linguistic-discourses.

The Indigenous people intentionally made the adventurer their ancestor because they wanted to challenge the colonial discourses through the stories of survivance. Binn Columbus the Stone's mother says that actually they were the one who via their imagination recreated the body parts from eyes to head and from belly to leg to a whole ancestral Mayan figure (Christopher Columbus), when he was torn apart by his voyage from the Old World. Thus, says Stone, "The Maya created Columbus" (Vizenor, 1991, p. 20), and the reason behind this recreation was the survival of the tribal people to make the tragedy of Christopher Columbus and his greed less tragic and turn him into something comic through oral traditions for the upcoming generations for their survivance. Thus, Christopher Columbus became a trickster healer in the tribal histories and stories, "He (Columbus) is the bear signature of our humour and survival" (Vizenor, 1991, p. 20). Survival through resistance has been tantamount for the Indian Tribes because they have been historically, politically, religiously and culturally persecuted since the advent of colonizers. The European colonizers not only seized the land from Native Americans but they had also introduced plethora of diseases such as measles, small-pox including many others. Once the Europeans found the tribal people humble, colonizers took their hospitality for servility. The colonizers not only introduced diseases and deprived these people of their culture (Cook, 1998). They also forced the tribes to leave their homelands and ought to live on reservations. But as these people (tribes) were driven out of their land they became tricksters who were not adopting the culture of the colonizers but subverting their culture to something new e.g. hybrid culture. They could not kill the Indian inside the tribal man. Thus, the novel narrates, "The old men, cheated out of their land, became tricksters, said Gracioso" (Vizenor, 1991, p. 23).

When Felipa is killed during recovering the remains of Pocahontas, the story diverges. Felipa's homicide prompts the establishment of the trickster society on the boundary between the United States and Canada. After her demise, the heirs move to Point Assinika and transport the House of Life and the Stone Tavern to their new residence. In the new country, the heirs make the Felipa Flowers Casino and construct the Statue of the Trickster of Liberty. Additionally, they start genetic treatment to develop a tribal identity and mend wounded individuals. The trickster state calls the public government's consideration, and a few examiners are shipped off control and report what occurs at Point Assinika. Also, the cannibal windigoo, who is continually attempting to obliterate the heirs, returns to scare them. Toward the finish of the novel, the heirs stand up to the windigoo and dominate the moccasin game. In this part of the novel, Vizenor portrays that colonial authority must be challenged till the freedom is secured.

The Point Assinika or Point Roberts is declared a sovereign state on the same date and month as the admiral of the sea discovered the New World. The date and month are October 12, 1992, which is the simulation of $12^{\text {th }}$ October 1492 . The reason behind the heirs of Columbus preference for a separate nation and geographical space is the inherent racism in the EuroAmericans. As the novel explains "The politics of race were never secure" (Vizenor, 1991, p. 121), that is why Stone Columbus openly calls to all the wounded people to come and join their nation on Carp Radio late night show. The protagonist also builds the simulation of the Statue of Liberty entitled 'the Trickster of Liberty', which is higher than the Statue of Liberty. The nation together was holding placards as a sign of tribal insurrection. Columbus takes back the 
New World at Point Roberts. Even the banner which is hoisted by the new nation at Point Roberts represents resistance and insurrection because of its red colour. Stone hoisted the red banner. He said, "this flag represents our survivance and the sovereignty of Point Assinika" (Vizenor, 1991, p. 123). The heirs of Columbus want a free state which would be free from colonial oppression. The state which the tribal people want slowly represents an anarchist Communist state, where there would be no property and land theft. The people will be free from the burden of taxes and prisons. Thus, the novel reads "The point was claimed by the heirs as a free state with no prisons, no passports, no public (or boarding) schools, no missionaries, no television, and no public taxation; genetic therapies, natural medicine, bingo cards, and entertainment were free to those who came to be healed and those who lived on the point" (Vizenor, 1991, p. 124).

The novel has got many anarchist elements and thus constantly makes references to Crazy Horse, Black Elk and Louis Riel. Crazy Horse and Black Elk were great leaders and warriors of tribal people and fought the historical battle 'Little Big Horn' or 'Custer's Last Stand' while Louis Riel too was a hero for the Canadian tribes but the colonizers considered him as an outlaw. Riel is associated with Metis Resistance in Canada (Powers, 1990). Since, Stone Columbus too fought for the rights of his people irrespective of any material gain for himself; he was compared to Louis Riel. The novel reads, "Stone has been compared to Louis Riel because both of them are cross bloods and leaders of the insurrections" (Vizenor, 1991, p. 127). Riel in the historical archives of Colonizers had been a traitor and was executed on the charge of treason but the tribal people still remember him as their hero and in fact he was as he stood for the rights of his people. An anonymous woman from the Oklahoma City calls the Carp Radio where Stone is the host of show, she tells Stone Columbus that you got the bingo and we got taxes. The colonizers' theft was so organized that they even stole the crime in the land allotment hoaxes, being done to the Indian tribes. The result was Indian tribes were forced to leave their lands and live on reservations with the intervention of the government agencies. Since, Stone Columbus is Anarchist in his thoughts and is challenging the colonial power, he is in danger of being charged with the same guilt of treason. But this time treason in not found in the man but in genes of the tribal people who are always carrying their memories and tribal past and stories to challenge the knowledge and power of the colonizers.

The historical backdrop of Columbus is retold in the initial three sections of "Blue Moccasins". From the fourth part onward, the focal point of the novel is chiefly on the historical backdrop of the heirs. Therefore, the attention isn't on the colonizer, but instead on the colonized. The story is devoted to the heirs as opposed to Columbus. However, Columbus is significant in the story as the ancestor whose account of colonization pushes the Natives' battle for their due rights and a better society. It is also said in the novel that the government on one hand kept silence on the insurrection and on the other hand they deployed its army on Point Roberts. History bears witness that the tribal people had been exploited on the basis of their blood and tribal race. Tribal people had been victimized on the basis of their blood racial extremism. Tribal people were "forever divided by the racist arithmetic measures of tribal blood" (Vizenor, 1991, p. 162), but as told already that through survivance the tribal people turn every evil move of the colonizers into their benefit. So, the racial difference which the U.S Government had made is utilized by the tribal people. In the novel Stone Columbus writes a letter to the president, in which he demands his due rights of tithes, "King Ferdinand and Queen Isabella signed seven documents and granted to Don Cristobol de Colon (Spaniard version of the name Christopher Columbus) in some satisfaction for what he hath discovered in the ocean sea, "a 
tenth of the gold, and other precious metals, spices, pearls, gems and other merchandise obtained in commerce and free of all taxes" (Vizenor, 1991, p. 160). Since, the agreement with Christopher Columbus has never been abrogated by treaties or war, so Stone Columbus the blood of the great explorer demands "to negotiate a cash settlement or some other agreement to resolve the tithe due for the past five centuries." (Vizenor, 1991, p. 163).

The story is separated into two fundamental areas, 'Blue Moccasins' and 'Point Assinika'; individually the names of a game and of the new country. Each part concerns a methodology to oppose colonization. In 'Blue Moccasins', the heirs attempt to recuperate their origins and history by getting back Columbus's remains and retelling the tale of the sea admiral. The homicide of Felipa sets the start of the subsequent area and shows that recuperating their origins was not an effective technique. In 'Point Assinika', rather than recuperating their past, the heirs create their origins by making the crossblood country and a hybrid tribal identification. In addition, the heirs deconstruct the colonial ideas of 'nation' and 'identity'. Since, the country is chosen the boundary between Canada and the United States, there is no boundary in Point Assinika. Additionally, there is no pure identity, and any individual who shares tribal qualities can have a hybrid identity and gotten ancestral. This is actually Survivance, survival through resistance. So, Duck Lucky says in the novel "Your genes could be the new treason" (Vizenor, 1991, p. 127). The colonizers might call Stone Columbus a traitor but the Heirs of Columbus and all tribal people called him a dreamer. Stone Columbus possesses the anarchist element of survivance in his genes that he has inherited from Christopher Columbus.

Stone Columbus was the paragon of resurrections. Therefore, the genes of Stone Columbus and his people were not common genes but possessed the signature of survivance. Not only their leader Stone Columbus resisted the authorities of the U.S Government but his fellow tribes men, women and children followed in the same footsteps, the novel reads thus "The heirs pursued the same mission of resistance and tribal independence" (Vizenor, 1991, p. 160) at the new nation at Point Roberts. Here Vizenor has explored the concept of a free state as the ultimate goal of anarchism. The heirs of Columbus especially Stone Columbus chose to reveal his resistance and anarchism through Radio because he believes television is the simulation of the real that the democratic government prefers. While Radio has no simulation, it is real. Radio voices the thoughts of millions of people and they make phone calls to ask questions. Furthermore, the Radio Voice which represents the voice of the oppressed class without any government intervention is accessible to all people who are willing to dream about a new world for the tribal people.

\section{Conclusion}

It is concluded at the end of the study that Anarchism is not an evil, which challenges the established principles of society. Most of the developed nations are haunted by the anarchist struggles because they are aware of its deteriorating results for the capitalist societies. Anarchists believe in social justice and balance, they do not believe in one state having different systems, classes and differences on the basis of caste, creed and well-being. They believe in freedom of expression, thoughts and action, a state which Vizenor has portrayed in The Heirs of Columbus. Vizenor has articulated the utopian concept of a free state in a colonial regime, where anarchists try to regain what is lost. The "heirs of Columbus" are the Anarchists and their free state is 'Point Assinika'. When Felipa Flower is killed in recovering the remains of Pocahontas, the heirs move to point Assinika. In Point Assinika, the statue of the "Trickster of 
Liberty" is higher than the Statue of Liberty, and the engraving on the sculpture vowed to heal the weary and clustered masses longing to breathe free. The Trickster of Liberty at last advances the opportunity that the American sculpture vowed to everyone coming from across the sea, yet never given to the Natives.

Point Assinika was "claimed by the heirs as a free state with no prisons, no passports, no public schools, no missionaries, no television, and no public taxation" (Vizenor, 1991, p. 124). In this part of the novel Vizenor depicts that it is where American technology and capitalism can add to mend individuals and turn them 'tribal'. Genetic treatments, natural medication, bingo cards, and amusement are types of healing, and are free to the individuals who come to be mended and those who live on the point. The aim of this utopian state is to make the world tribal and make a widespread cross blood identity. Any individual who needs to be tribal is acknowledged in Point Assinika. Notwithstanding, Stone clarifies that he opposes any thought of blood quantum and racial identification. Thus, the tribal universal identity is considerably more identified with tribal consciousness than to ancestral blood, and it is given through genetic therapy to those, who are devoted to heal rather than steal tribal cultures. Thus, Vizenor clarifies that every culture needs a free state, where individuals can preserve their identity.

\section{References}

Awan, T., \& Fatima, S. (2019). Twilight in Delhi and shadows of the Pomegranate tree: A comparative, postcolonial discourse. Academic Research Journal, 10(2), 74-82. http://www.savap.org.pk/journals/ARInt./Vol.10(2)/ARInt.2019(10.2-08).pdf

Berkman, A. (1977). ABC of Anarchism ( $1^{\text {st }}$ Ed.). Freedom Press.

Cook, N. D. (1998). Born to die: Disease and new world conquest, 1492-1650. Cambridge University.

Creswell, J. W. (2007). Qualitative inquiry and research design: Choosing among the five approaches $\left(2^{\text {nd }}\right.$ Ed.). Sage Publications.

Goldman, E. (1910). Anarchism and other essays (1 ${ }^{\text {st }}$ Ed.). Mother Earth Publishing Association.

Igwenagu, C. (2016). Fundamentals of research methodology and data collection. LAP Lambart Academia Publishing. https://www.researchgate.net/publication/303381524

Kinna, R. (2005). Anarchism: A beginner's guide ( $1^{\text {st }}$ Ed.). Simon and Schuster.

Kipling, R. (1899). White Man's burden ( $1^{\text {st }}$ Ed.). Doubleday and McClure Co.

Kumar, R. (2019). Research methodology: A step-by-step guide for beginners ( $3^{\text {rd }}$ Ed.). Sage Publications.

Lord, L., \& Burke, S. (1991). America before Columbus. US News and World Report, 8, 2237.

Mishra, S. B., \& Alok, S. (2017). Handbook of research methodology: A compendium for scholars and researchers. Educreation Publishing.

Patton, M. Q. (2002). Qualitative Research and Evaluation Methods (3 ${ }^{\text {rd }}$ Ed.). Sage Publications.

Powers, W. (1990). When Black Elk speaks, everybody listens. Social Text, 24(1), 43-56. https://doi.org/10.2307/827826

Prichard, A. (2013). Justice, order and anarchy: The International Political Theory of Pierre Joseph Proudhon ( $1^{\text {st }}$ Ed.). Routledge. 
Proudhon, P. J. (1876). What is property? Or an inquiry into the principle of right and of government $\left(1^{\text {st }}\right.$ Ed.). Princeton University.

Rooum, D. (2016). What is Anarchism? An introduction ( $2^{\text {nd }}$ Ed.). PM Press.

Sabzalian, L. (2019). Indigenous children's survivance in public schools ( $1^{\text {st }}$ Ed.). Routledge.

Said, E. (1978). Orientalism ( $1^{\text {st }}$ ed.). Vintage Books.

Stanton, C. R. (2020). Survivance story work: Expecting more from ourselves: Indigenous children's survivance in public schools, by Leilani Sabzalian. Theory and Research in Social Education 48(2), 1-7. https://doi.org/10.1080/00933104.2019.1678329

Stratton, B. J. (2019). Transnational narratives of conflict and empire, the literary art of survivance in the Fiction of Gerald Vizenor. Transmotion, 5(1), 11-32. https://doi.org/10.22024/Unikent/03/tm.581

Vizenor, G. (1991). The Heirs of Columbus. Wesleyan University.

Vizenor, G. (1992). Manifest manners: The long gaze of Christopher Columbus. Boundary 2, 19(3), 223-235. https://doi.org/10.2307/303555

Vizenor, G. (2008). Survivance: Narratives of native presence ( ${ }^{\text {st }}$ Ed.). University of Nebraska. 